\title{
Origins of the Kalinowszczyzna district in Lublin: history, design principles and current condition
}

\author{
Michał Dmitruk \\ m.dmitruk@pollub.pl \\ Faculty of Civil Engineering and Architecture, Department of Architecture, \\ Urban and Spatial Planning, Lublin University of Technology
}

\begin{abstract}
Lublin developed rapidly at the turn of the 1960s and 1970s. Large residential districts were designed on rural areas surrounding the city. Lublin was expanded in almost every geographical direction, in accordance to the principles specified in the 1959 city master plan. The Kalinowszczyzna district was located in the north, covering local hills and ravines, and replacing the former farm and manor it was subsequently named after. The housing estates constructed there were erected mainly by means of prefabricated elements, and included both flats and shops. They also played cultural and administrative functions. The plan's implementation was launched in 1963 and came to an end in 1980s. Kalinowszczyzna is currently one of 27 administrative districts of Lublin and constitutes an essential part of the city.
\end{abstract}

Keywords: concrete slab, multifamily housing architecture, prefabrication, modernization, revival, humanization, urban planning, Kalinowszczyzna, Lublin

\section{Historical background}

The area of current Kalinowszczyzna is greatly important from the historical, functional and landscape-related point of view. The name, given in the $19^{\text {th }}$ century ${ }^{1}$ to mark the administrative area of the district, comes from the name of the land owners: the Kalinowski family. The district is currently informally referred to as "Kalina". It also used to be called "Firlejowszczyzna", as Zbigniew Firlej, a regional governor, would move his settlers there in the $17^{\text {th }}$ century. Its other names include "Przedmieścia Lwowskie"2 and "Słomiany Rynek" ${ }^{3}$. The Lublin suburbs, known until the $18^{\text {th }}$ century as Przedmieście Lwowskie ${ }^{4}$ constituted an important, independent and well-functioning settlement due to its location close to the high road leading to Lviv ${ }^{5}$. There are still visible traces of the past colony located in-between the Bystrzyca and Czechówka rivers, which can be identified both on the central Lwowska Street and on the Słomiany Rynek street, tha latter one being a reminescence of the historic town trade square. The area is also a trade-oriented one nowadays, while the main trade location is the local out-of-use football stadium. Building in Kalinowszczyzna was determined by the road system from Lublin towards the Bystrzyca bridge. Some of these roads have been preserved until this day, in the form of the following streets: Sienna, Towarowa, Kalinowszczyzna and Białkowska Góra ${ }^{6}$. In turn, the Saint Florian's roadside shrine is the only present-day reminescence of the once-existing Floriańska street.

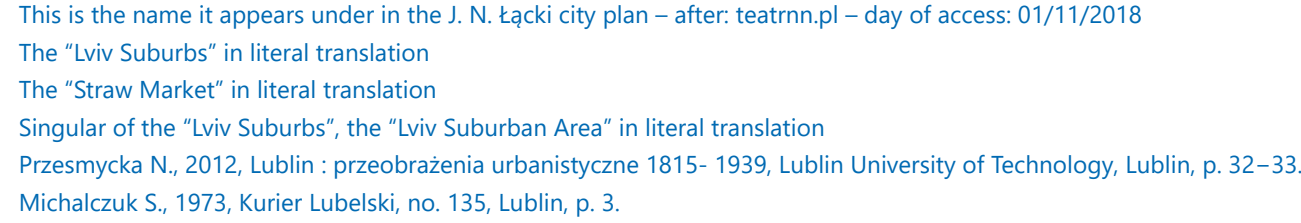


A number of Kalinowszczyzna places and buildings is of great architectural and cultural value. For instance, a post-Augustinian monastery (erected in the years 1647-1667 and expanded in 1685) ${ }^{7}$ together with the Saint Agnes church, constitute an outstanding example of the Lublin Renaissance style (with Baroque elements). The monastery is an alement of the city skyline, well-exposed on the hill and perfectly visible from far away. At the same time it is an excellent scenic viewpoint facing the old city hill. Another, post-Franciscian monastery erected in the years 1626-1693, is located at the beginning of the Kalinowszczyzna street, at the bottom of the Grodzisko hill. Both monasteries used to be landmarks in the city landscape, which is no longer the case due to the urbanization processes of the 1970s resulting in a new residential area with simple and raw style of 11 -storey buildings aggressively dominating the skyline.

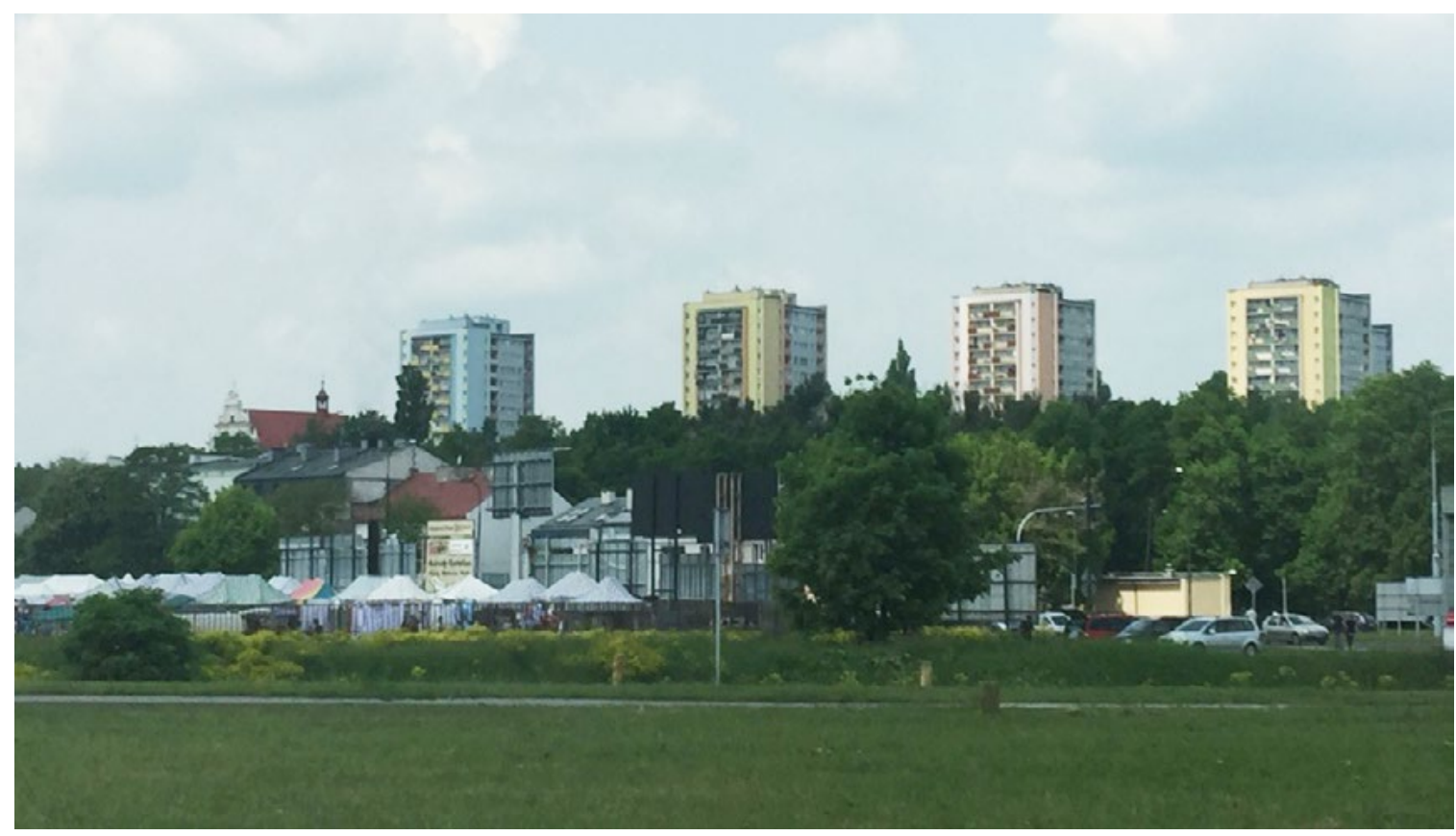

Fig. 1. The skyline of the Kalinowszczyzna district - view over the Saint Agnes church. Author: Michał Dmitruk

The current Kalinowszczyzna housing area was referred to by the Lublin Jewish community as "Wola" in the $17^{\text {th }}$ century when the Jewish municipality existed. There was a synagogue and a $16^{\text {th }}$-century cemetery (being the oldest cemetery in Poland) located on the Grodzisko hill (currently neighbouring the post-Augustinian monastery). In the $19^{\text {th }}$ century, Kalinowszyzna played mainly the commercial service and trade functions, with e.g. Pejsach Brykman, Lejzor Lidzki and Szmul Ajchenbaum tanneries. An old paper mill was replaced by the Krauze mill ${ }^{8}$, preserved until this day. The current Salesian church located at the crossing of the Lwowska and Kalinowszczyzna streets once served as the cloth factory.

A number of undesired factors influenced the development of Kalinowszyzna. At the same time, the Jewish community became poorer. In 1655 , the settlement and its monasteries were completely plundered by the Cossack army, while in 1831, the majority of facilities were burnt down due to the reckless operating with fire by the Russian armed forces. Once the treaty of Zamojski was signed in the $19^{\text {th }}$ century, the prestige of Lwowskie Przedmieście decreased. While trade was continued, it lost its significance due to lower transit. 


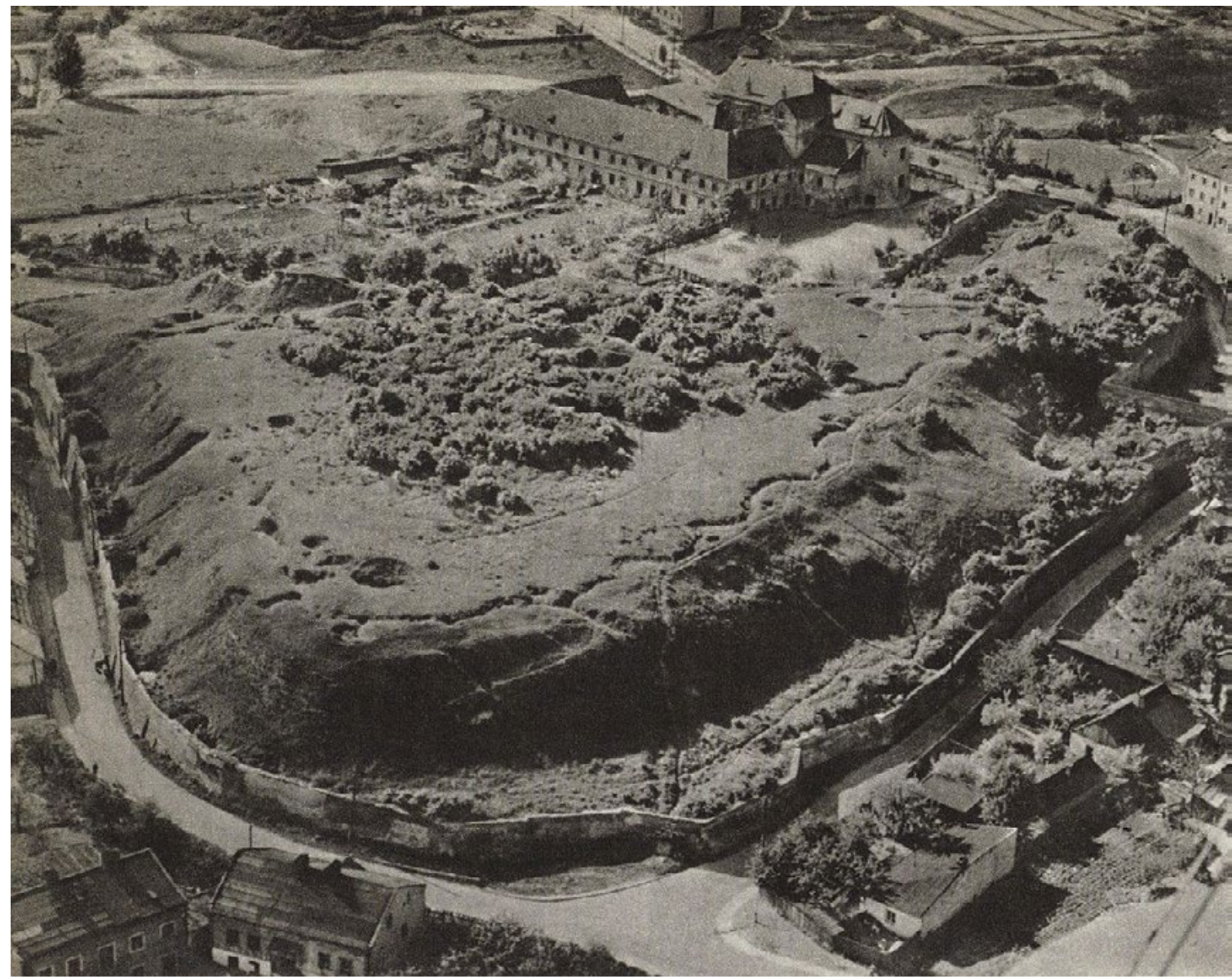

Fig. 2. View at the Our Lady, Supporter of the Faithful church and the "Grodzisko" hill with Jewish cemetery. Year 1964. Author: P. Krassowski - public domain.

In the 1960s, large housing estates with commercial service centres were erected, according to the master plan of 1959 by the The Urban Planning Office of the Municipal National Council ${ }^{9}$ in Lublin led by arch. Romuald Dylewski ${ }^{10}$. Architects: Rita and Tadeusz Nowakowscy were the authors of the 30 -lecia PRL ${ }^{11}$ housing area (1969-1975) design. The design included 19 buildings later inhabited by circa 5,000 people living in 1,706 flats. In turn, the Niepodległości ${ }^{12}$ housing estate's construction was launched in 1972, resulting in 30 housing buildings (high-rise and medium-rise ones, inhabited by 6,500 people living in 2,318 flats). The construction of modern, concrete-slab-buildings completely changed the ambiance and landscape of the area, from a cozy, small-town one to a big-city district, well-established in the city skyline. For instance, the gorge, later constituting the 30-lecia PRL housing estate's compositional axis, was once filled with the small Muchawiec river neighbouring timber houses surrounded by gardens and orchards. These were either subject to natural degradation or destroyed on purpose and replaced by the housing estate infrastructure.

The district is currently composed of four housing estates: Osiedle Kalinowszczyzna, Osiedle 30-lecia, Osiedle Niepodległości and Osiedle 40-lecia. There are also large service and administration pavillions in the district centre. The 30-lecia housing area hosts a Roman Catholic cemetery. 


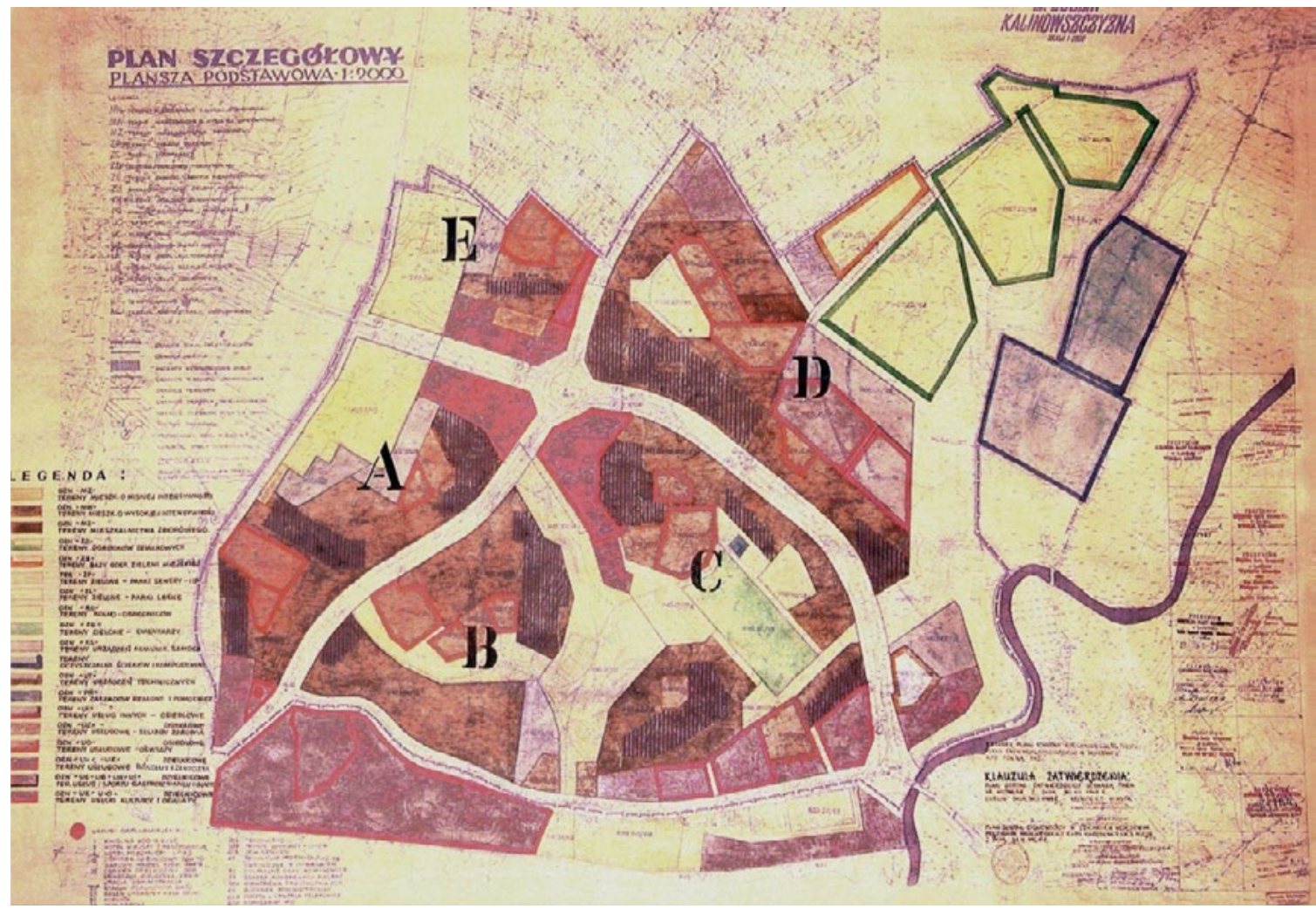

Fig. 3. The division of the Kalinowszczyzna district into housing estates, according to the detailed plan of 1964 . Source: Archive of the City Council in Lublin.

\section{Original design principles}

In 1959, the Economic Committee at the Presidency of the Council of Ministers approved the Lublin Master Plan developed by the The Urban Planning Office of the Municipal National Council led by arch. Romuald Dylewski. This constituted the legal basis for creating a new district - Kalinowszczyzna. The plan's key element was the creation of large city districts with their own service, trade and administrative centres. They were supposed to respond to the needs and requirements of the rapidly-developing city, which the central district alone could not meet ${ }^{13}$, as specified in the analyses. In addition, the need to enlarge the city administrative borders, as well as the degree of enlargement that could be sufficient and optimum were subject to a debate.

Consequently, the location of two industrial disctricts, i.e Tatary and Wrotków, was set, similarly to six housing areas, including Kalinowszczyzna ${ }^{14}$. As Figure 4 shows, each new district had a commercial centre for the area inhabitants. According to the plan's author, arch. Romuald Dylewski ${ }^{15}$, the initial plan to have these centres was successfully carried out only in the LSM district along the Tomasz Zan street. That notwithstanding, a clear and well-functioning central part is also visible along the Gen. Władysław Anders avenue in Kalinowszczyzna (Fig. 5) where multi-storey commercial buildings with terraces subserving pedestrian traffic are located.

The original plan was very well received, which was mainly due to conducting meticulous analyses of the previous plans, selecting proper solutions and rejecting those which were in conflict with the natural lanscape or up-to-date at that time city development trends of Western Europe. The development of transport and communication was also included in the plan. The lengths of pedestrian routes within housing areas were optimised. 
The mentioned new districts of Lublin were located on hills divided by river valleys or rainwater drainage systems becoming their natural borders. Importantly, adequate topographic maps were not available at the time of the planning, therefore the design teams were forced to revisit and enhance their plans in situ. The natural distance among particular city districts was strengthened by greenery areas or communication paths around the housing estates. According to the plan, the building density was to increase together with the proximity to the district centre. The bigger the distance to the centre, the more loosely the area was built. The design was governed by the principle of "even value distribution"16. The principle ensured each housing estate's full and equal access to services, education and cultural facilities such as cinemas, theatres or community centres. Due to insufficient number of flats, it was decided not to introduce any new industry into Kalinowszczyzna until 1965. Instead, the focus was on providing for flats for 30,000 inhabitants, and modernising the already existing industrial facilities. The housing estates were in satellite arrangement, divided by streets and roads. In turn, footbridges were placed over the streets to enable free pedestrian movement. Kalinowszczyzna has been crucial for the Lublin's landscape, as the district's buildings complete the northern skyline of the old city. Importantly, only a well-designed building arrangement on the hills could and can ensure a harmonious blend of old, historical, and new city tissue.

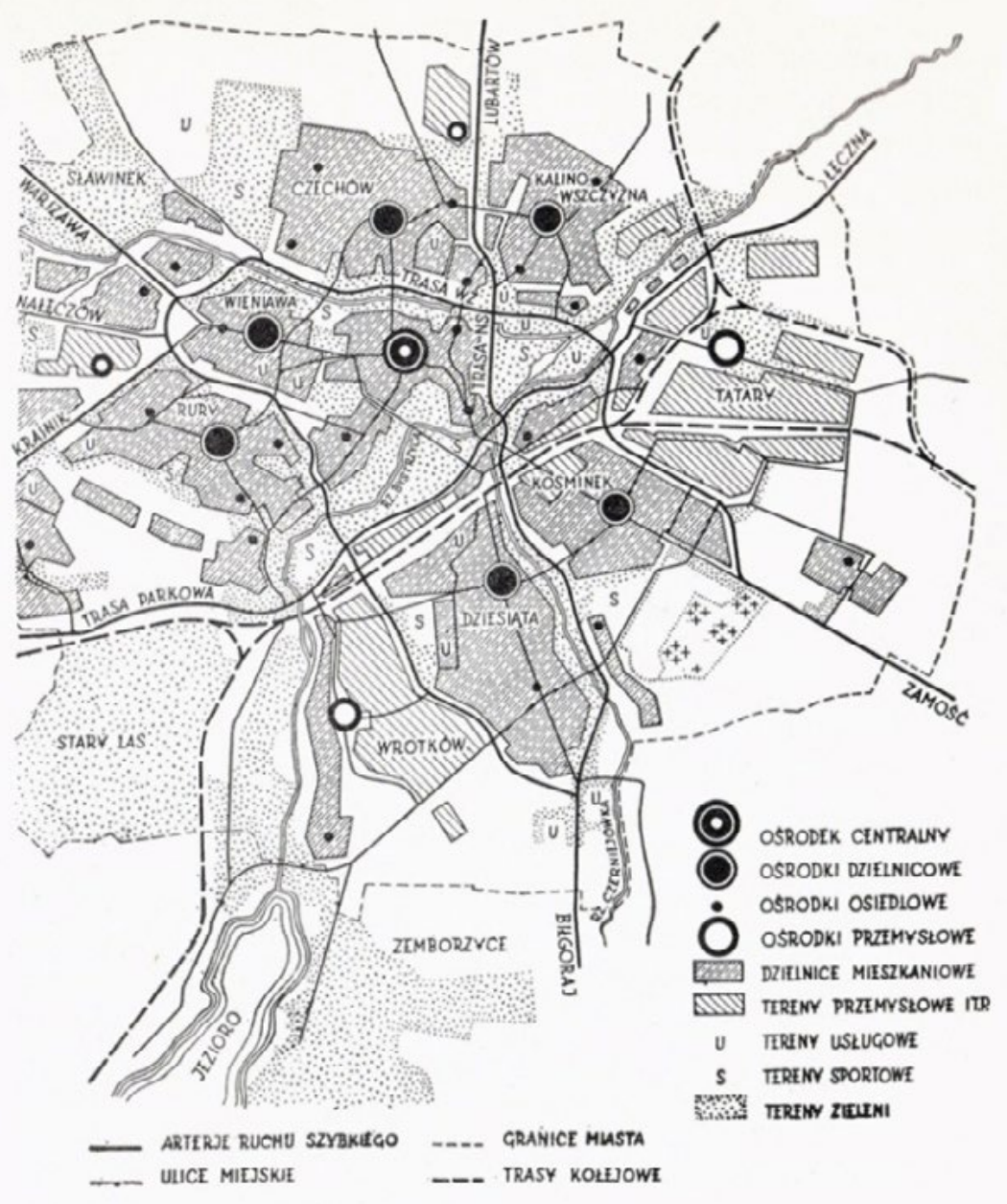

Fig. 4. Illustration from the General Master Plan of Lublin of 1959.

Source: Romuald Dylewski private archives 
Rita and Tadeusz Nowakowscy were given the task of designing a coherent, modern and functional district. The duo was renowned for e.g. their project of the City Hall office building at the Wieniawska 14 street (in 1978), completed in cooperation with Jerzy Androsiuk, Stanisław Fijałkowski and Janusz Makowiecki. According to the new district's plan, the buildings were to blend into the natural landscape. The large gorge was to serve as the walking area for inhabitants and the "green lungs" of the estate. It was also important to create collision-free vehicle and pedestrian traffic, and this was achieved by means of the footbridges over the Lwowska and Gen. Władysław Anders ${ }^{17}$ streets protruding through the estates.

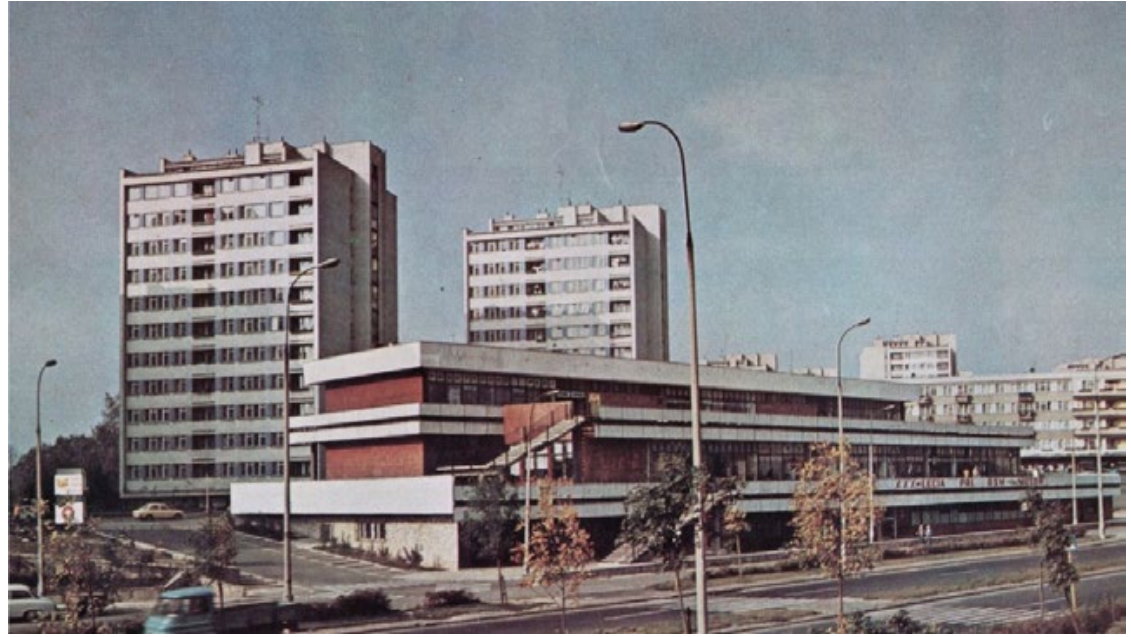

Fig. 5. Comercial buildings along the General Władysław Anders avenue in Lublin.

Author: Zbigniew Zugaj

The "Motor" Workers' Housing Cooperative ${ }^{18}$, led by Eugeniusz Kowalski, was launched on the $18^{\text {th }}$ of November 1960. The aim of this cooperative was to build flats for the workers of a prominent Truck Factory ${ }^{19}$ in Lublin. The first housing estates were built in 1963 and they are in the closest proximity to the old town now, north of the Tysiąclecia avenue, along the Lwowska street. The designers used the pre-existing ravines and gorges as natural markers of the buildings' arrangement. The Lwowska street was introduced along one of these ravines, acting as a compositional axis of the Kalinowszczyzna housing estate. Another ravine remained unbuilt and currently constitutes a natural eastern border of the estate, subserving leisure purposes of the inhabitants. The buildings were erected using traditional construction technology. There are 23 low-rise and medium-rise (up to 5 overground floors) linear housing blocks, 4 medium-rise towers and 19 high-rise, 11-storey towers ${ }^{20}$. Interestingly, the blocks along the Lwowska street are arranged in a clear linear way at the same time being equipped with groundfloor shops which do exist until this day (Fig. 6).

The housing estate, replacing a number of the $19^{\text {th }}$-century houses and shops was received with enthusiasm by the first inhabitants. As one of them, Zbigniew Miazga, writes: "This is the beginning of the end of Kalinowszczyzna's bad reputation, the district of poor houses, mediocre and gloomy streets, suburban folclore..." ${ }^{21}$. In fact, the architecture and the ambiance of the disctrict changed radically. There are only some of the old houses, manors and shops left until today, and the suburban folclore is no longer present. One question remains unanswered, namely: Were not these elements worth preserving while planning the new city tissue?

Another housing estate, namely: the 30-lecia (PRL) one, was built to the east of the ravine in the years: 1969-1975. Rita and Tadeusz Nowakowscy, the architects of the Miastoprojekt Lublin architectural office, designed three 11-storey tower buildings' units on the southern hill. Another unit composed of five similar buildings was erected next to the Saint Agnes church. In addition, along the Gen. Władysław Anders avenue, and

\footnotetext{
17 Previously: Bolesław Bierut street and Włodzimierz Lenin avenue, respectively.

18 Robotnicza Spółdzielnia Mieszkaniowa "Motor" in Polish

19 Fabryka Samochodów Ciężarowych in Polish

20 In 2012, the tissue became denser, as two 10-storey buildings were erected next to the Berbecki roundabout.

21 Kazimierczak- Smuga B. [ed.], Nowy Lublin. Osiedla RSM „Motor”, Przyjaźni, XXX-Lecia PRL, Niepodległości. Robotnicza Spółdzielnia Mieszkaniowa "Motor" w Lublinie, Lublin.
} 
south to the gorge, linear 5-storey blocks were arranged in the shape of crescents, by the same token forming specific urban interriors. The described district was the first one in Lublin where prefabricated elements (the so-called WB, OWT-67) were used for residential building. The high-rise buildings stand out in the city skyline. At the same time, these changes negatively affected the visual reception of the Saint Agnes church. While located on a hill and being one of the most valuable architectural elements of the area, the church no longer dominates the skyline (Fig.1). The churches located on Lublin's hills (Czwartek, the castle hill, the Staromiejskie hill with the Dominicans' church and, previously, the Saint Michael's parish church, as well as the above mentioned Saint Agnes church), constituted a set of visual landmarks, and this coherent image was destroyed by the poorly arranged architecture of the 30-lecia housing estate. Similarly, it remains unclear why the housing estate surrounds a cemetery (with the cemetery becoming the estate's central part). It is a large building with shops, along the Gen. Władysław Anders avenue that plays the key role in the housing area. Its three overground levels are dedicated to trade and accessible to pedestrians due to large terraces (galleries) and a footbridge connecting it to the neighbouring housing estate (Fig. 5). The facility, together with other buildings within the Niepodległości housing estate, were to function as a district centre, included in the above mentioned Lublin Master Plan by Romuald Dylewski. 5,000 inhabitants are currently living there in 1,706 flats and 21 housing blocks 22 .

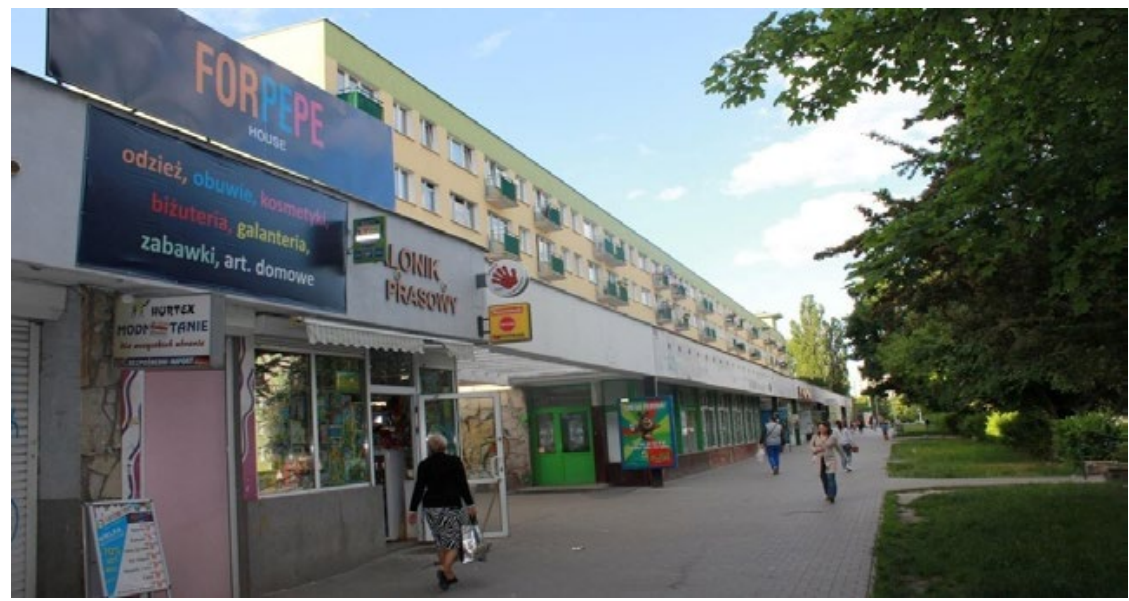

Fig. 6. Block of flats with shops on the ground floor, near the Lwowska street in Lublin.

Author: Michał Dmitruk

The Niepodległości and 40-lecia (PRL) housing estates, located in the northern part of the district, have quite similar layout and architecture, being also based on similar design principles. Therefore, they may be discussed jointly. The only element that visually divides these two areas is the Niepodległości street axis. Similarly to the other parts of Kalinowszczyzna, this one was designed by Rita and Tadeusz Nowakowscy. The estate is located on the verge of the Bystrzyca river valley, at the same time providing for a distinguishable skyline on the east side of Lublin (Fig. 7). Looking at the skyline, an observer would first recognize the 5-storey linear blocks standing perpendicularly to the visual axis, with high-rise towers in the background, enriching the view. The estate's northern multi-family buildings neighbour the Ponikwod detached houses. As the youngest of all the Kalinowszczyzna'z estates, these ones are characterised by a large number of shops, as well as educational, medical and sports facilities. A clearly distinguishable commercial centre is located around the Berbecki roundabout, hosting the National Healthcare Fund ${ }^{23}$, kindergartens, rehabilitation facilities, post office and a number of big and small shops. There are also 5 sports playing fields, 1 seasonal ice skating rink, a junior high school, kindergarten and many shops nearby. Typically of Kalinowszczyzna, the inter-block spaces are vehicle traffic-free. Instead, open parking lots were located along main streets (with smaller access roads) and large parking units were placed in the outskirts. By the same token, blocks are now surrounded by rich greenery which has already grown and successfully breaks the monotony of concrete slab architecture. 


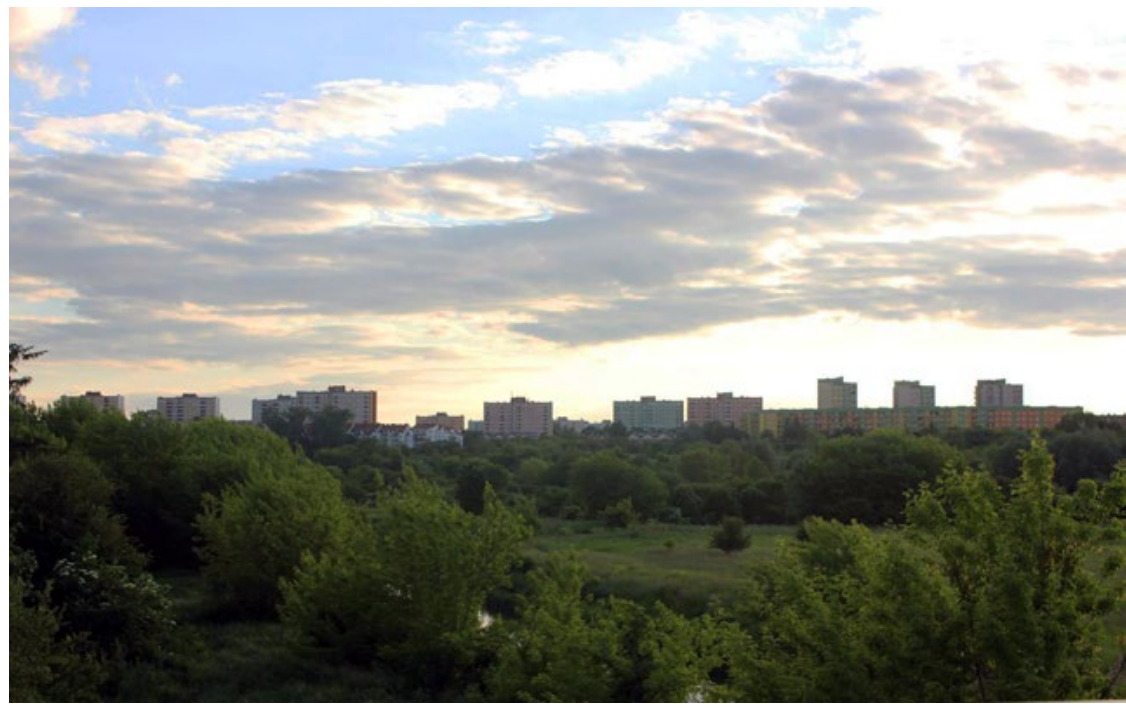

Fig. 7. The skyline of the 40-lecie estate in Lublin. Seen from Bystrzyca river bank.

Author: Michał Dmitruk

\section{Current condition}

Only some of the initial architectural and urban solutions have been preserved until today. On the other hand, e.g. the idea of a collision-free footbridge for pedestrians above the Lwowska street proved unsuccessful in practice. Crossing the footbridge required climbing two flights of stairs which made people choose another crossing at the level of and directly through the street, even if it required waiting for the cars to pass. Finally, at the cost of loosing collision-free communication, the footbridge was dismantled in 2010 due to its poor technical condition, and the only footbridge remaining in the district is the one above the Gen. Władysław Anders avenue. The Kalinowszczyzna district tissue has been densifying since then, with new buildings being still erected. The most recent constructions include two high-rise buildings with a supermarket, at the Lwowska and Anders corner. A Carrefour supermarket and the Saint Antoine Padewski parish church were built earlier, while a number of blocks and terraced houses were erected in the 1990s. In 2011, the MKS ${ }^{24}$ "Kalina" sports club's playing field was built, which constituted an important yet unsuccessful addition to the estate, inaccurately placed in the natural gorge running between two housing areas, thus creating a visual a communication barrier for pedestrians. Importantly, the Bolesław Bierut statue, which despite being a communist monument constituted a significant aesthetic element of the district, was dismantled as a result of political system's transformations. Currently, there is a large housing unit being constructed in the northern part of the estate, while a large part of the square remains undeveloped.

Another serious issue lies in colour selection for the blocks and towers, following their thermal modernisation. The buildings were predominantly of soft colours (usually white and grey) with occasional harder and more vivid accents often in the form of colourful balcony plates. While slightly monotonous, the buildings matched one another. In contrast to that, current colours and patterns seem to be randomly selected for particular buildings, especially in the case of the Niepodległości estate, which not only neglects the rules of harmonious and coherent design but even triggers visual chaos. The impression of chaos is intensified by numerous and visually aggressive advertisement signs and banners, which is demonstrated below, by means of before-and-after pictures. 


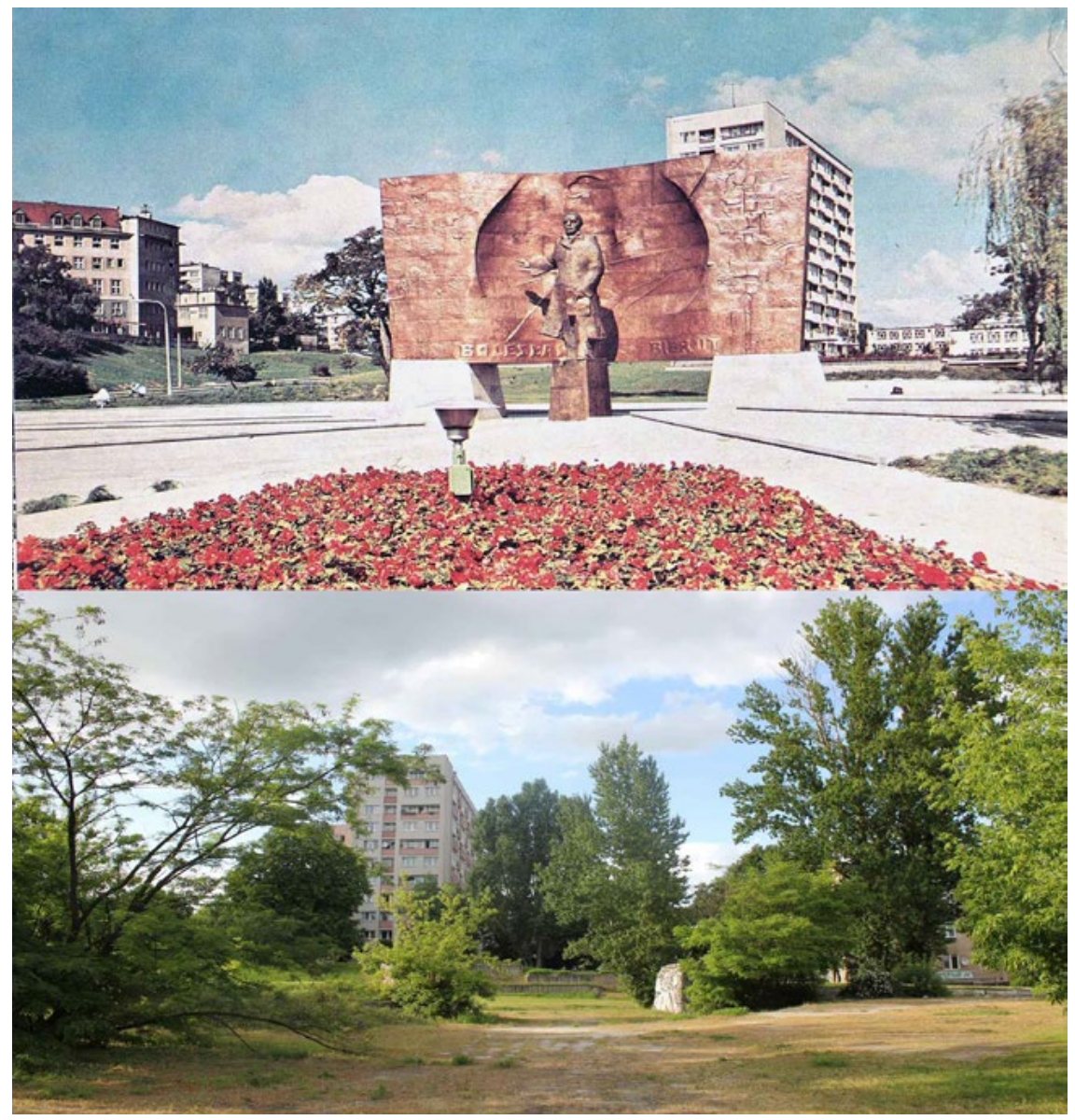

Fig. 8. No-longer-existing monument of Bolesław Bierut at the Singer's square in Lublin and present view (06/06/2017).

Authors: Zbigniew Zugaj/ Michał Dmitruk

The 40- and 50-years old, and therefore already mature and dense, greenery constitutes a significant added value for the estate. There are numerous trees, bushes and green areas being dilligently cared after by the local housing cooperatives. As specified in the estate's Management Office's economic report of $2014^{25}$, a wide variety of modernization works are conducted, including painting, masonry, plastering, road maintenance, technical installations' servicing (replacement), and other works such as installing surveillance or bird prevention systems ${ }^{26}$. What is more, the inhabitants play a crucial role in the decision-making process regarding maintanance and modernization, by submitting and presenting their needs to the Management Office. By the same token, not only the inhabitants' wellbeing is increased, but so is their feeling of responsibility and impact they have on the quality and development of their district.

The number of maintenance works specified in the report is impressive, while keeping the buildings' colours coherent calls for improvement. Similarly, a number of decisions are being made without proper knowledge of the original estate plan, for instance - regarding the previously mentioned fenced playing field in the gorge, or footbridge dismantling. It is only the participation and engagement of qualified parties that can restore the desired aesthetic character of Kalinowszczyzna. 


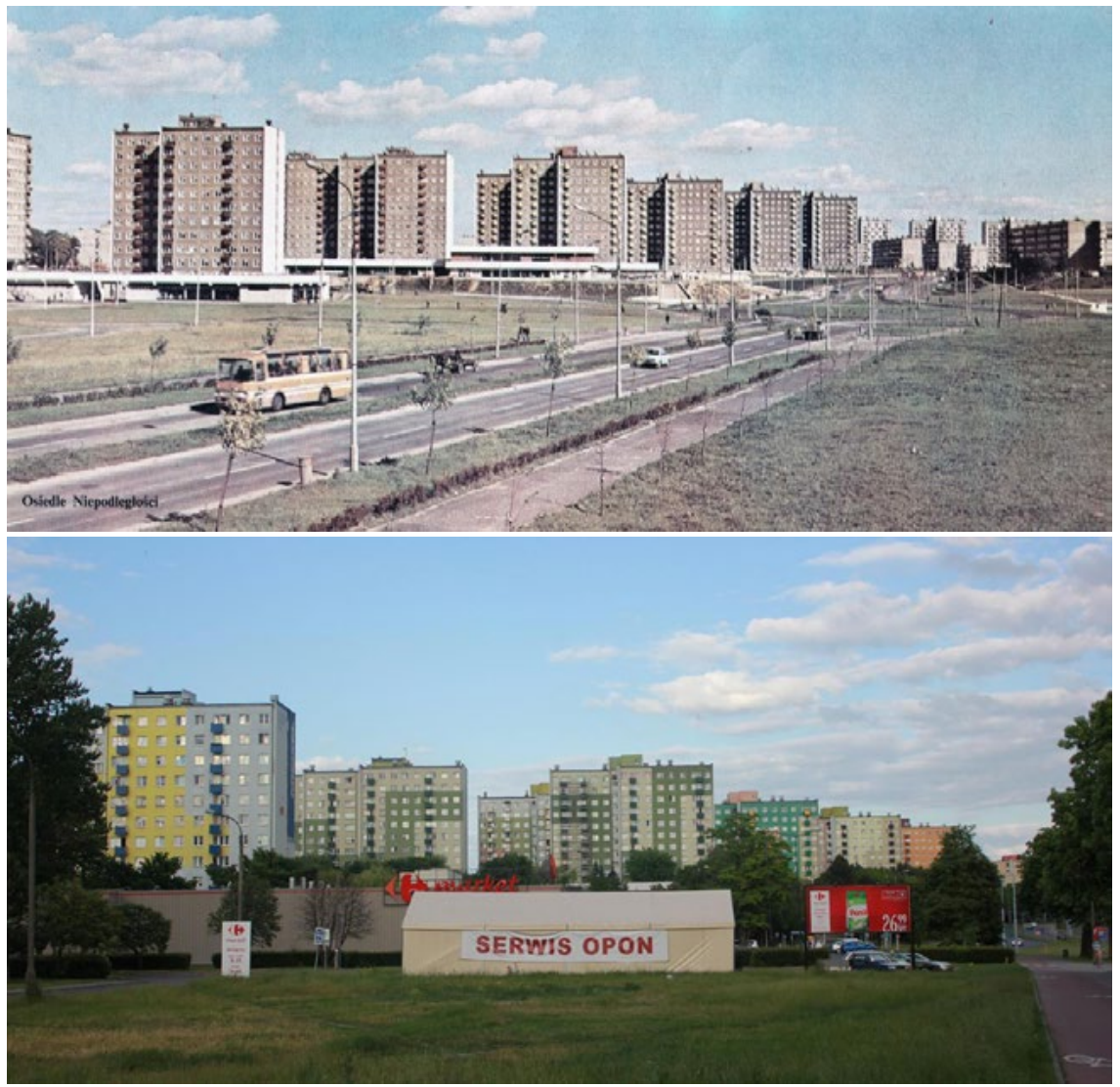

Fig. 9. Niepodległości district in Lublin - original condition and the current state.

Authors: Zbigniew Zugaj/ Michał Dmitruk

\section{References}

[1] Gawarecki H., Gawdzik C., 1964. Lublin, krajobraz i architektura, Arkady, Warszawa.

[2] Kazimierczak- Smuga B. [ed.], Nowy Lublin. Osiedla RSM "Motor", Przyjaźni, XXX-Lecia PRL,

[3] Niepodległości. Robotnicza Spółdzielnia Mieszkaniowa "Motor" w Lublinie, Lublin.

[4] Michalczuk S.,1973, Kurier Lubelski, no. 135, p. 3, Lublin.

[5] Michalska G.,1995, Młyn braci Edwarda i Henryka Krausse przy ul. Działkowej 45, [in:] Czerepińska J., Michalska

[6] G., Studziński J., Katalog architektury przemysłowej w Lublinie, v. I p. II, p. 8, manuscript written for the National Monument Protection Office (Państwowa Służba Ochrony Zabytków), Lublin.

[7] Miłobędzki A., 1980, Architektura polska XVII wieku, Państwowe Wydawnictwo Naukowe, Warszawa.

[8] Przesmycka N., 2012, Lublin : przeobrażenia urbanistyczne 1815- 1939, Lublin University of Technology, Lublin.

[9] Sprawozdanie z działalności gospodarczej Administracji Osiedla „Kalinowszczyzna" za 2014 r. [„Kalinowszczyzna” housing estate's Management Office's economic report of 2014.]

\section{Online resources}

[1] kolejarz.lublin.pl

[2] pl.wikipedia.org/wiki/Kalinowszczyzna

[3] teatrnn.pl 